\title{
TAXONOMICAL AND CHOROLOGICAL NOTES 3 (28-37)
}

\author{
Attila TAKÁCs ${ }^{1}$, Kornél Barát ${ }^{2}$, János CsIKY $Y^{3}$, Éva R. CsI KYNÉ ${ }^{4}$, Gergely \\ KIRÁlY ${ }^{5}$, Timea NAGY ${ }^{6}$, Viktor PAPP ${ }^{7}$, Dávid SCHMIDT ${ }^{8}$, Bendegúz TAMÁs ${ }^{4}$ \\ and Zoltán BARINA9 \\ ${ }^{1}$ Department of Botany, University of Debrecen, \\ H-4032 Debrecen, Egyetem tér 1, Hungary; limodorum.abortivum@gmail.com \\ ${ }^{2}$ Institute of Biology, University of West Hungary, \\ H-9700 Szombathely, Károlyi Gáspár tér 4, Hungary; barath.kornel@ttk.nyme.hu \\ ${ }^{3}$ Department of Ecology, Institute of Biology, Faculty of Sciences, University of Pécs, \\ H-7624 Pécs, Ifjúság útja 6, Hungary; moon@gamma.ttk.pte.hu \\ ${ }^{4}$ Lajos Nagy Grammar School of the Cistercian Order, H-7621 Pécs, Széchenyi tér 11, Hungary \\ ${ }^{5}$ Institute of Silviculture and Forest Protection, University of West Hungary, \\ H-9400 Sopron, Bajcsy-Zsilinszkyu. 4, Hungary; kiraly.gergely@nyme.hu \\ ${ }^{6}$ Department of Plant Sciences and Biotechnology, University of Pannonia, \\ H-8360 Keszthely, Festetics u. 7, Hungary; tima.nagy@gmail.com \\ ${ }^{7}$ Department of Botany, Szent István University, \\ H-1518Budapest,.Pf. 53, Hungary; papp.viktor@kertk.szie.hu \\ ${ }^{8}$ Institute of Botany and Nature conservation, University of West Hungary, \\ H-9400 Sopron, Bajcsy-Zsilinszkyu. 4, Hungary; schmidt.david@nyme.hu \\ ${ }^{9}$ Department of Botany, Hungarian Natural History Museum, \\ H-1431 Budapest,.Pf. 137, Hungary; barina.zoltan@nbmus.hu
}

Takács, A., Baráth, K., Csiky, J., Csikyné, R. É., Király, G., Nagy, T., Papp, V., Schmidt, D., Tamási, B. \& Barina, Z. (2016): Taxonomical and chorological notes 3 (28-37). - Studia bot. hung. 47(2): $345-357$.

\begin{abstract}
The third part of the recently launched series includes miscellaneous new records from fungi to vascular plants. New chorological records of one fungi, two pterids, and seven flowering plants are provided here: one new for Hungary (Dittrichia graveolens) and two for Albania (Drypoteris expansa, Salvia aethiopis), two new for South Hungary (Carpinus orientalis and Moneses uniflora), one new for the Mecsek Mts (Deschampsia flexuosa), one confirmed in the Köszeg Mts (Dryopteris affinis), one new for the Zemplén Mts (Eleocharis uniglumis), one for the Cserhát Mts (Himantoglossum adriaticum), and one for the Buda, Börzsöny, and Bükk Mts (Xylobolus subpileatus). At the same time, Xylobolus subpileatus and Carpinus orientalis had only one previously known native locality in Hungary while the others are regionally rare in Hungary. Carpinus orientalis was likely planted in the reported locality, Dittrichia graveolens is introduced, Deschampsia flexuosa likely introduced, while the other reports refer to native occurrences of the discussed taxa.
\end{abstract}

Key words: Asteraceae, Betulaceae, Cyperaceae, Dryopteridaceae, Ericaceae, Lamiaceae, Poaceae, Stereaceae 


\title{
INTRODUCTION
}

This paper is the third part of the series launched in Studia botanica bungarica focusing on the new chorological records, nomenclature, and taxonomy of plant species from algae to vascular plants and fungi (BARINA et al. 2015, PAPP et al. 2016).

\section{MATERIAL AND METHODS}

Nomenclature of fungi and vascular plants from the territory of Hungary follows MycoBank, and KirÁly (2009) while for other areas The Plant List (2013). Codes of the Central European Flora Mapping System are in square brackets.

\section{NEW RECORDS WITH ANNOTATIONS}

\author{
Fungi
}

\section{(28) Xylobolus subpileatus (Berk. et M. A. Curtis) Boidin (Stereaceae)}

Hungary, Nógrád County, Börzsöny Mts: near Hont, on Quercus cerris log, $48.03547^{\circ} \mathrm{N}$, 18.98140 ${ }^{\circ}$ E; leg. et det. V. Papp, 08.10.2014, BP 106938. - Hungary, Nógrád County, Börzsöny Mts: near Hont, on Quercus cerris log, $48.03112^{\circ} \mathrm{N}, 19.01738^{\circ} \mathrm{E}$; leg. et det. V. Papp, 08.10.2014, BP 106939. - Hungary, Nógrád County, Börzsöny Mts: near Nagyoroszi, on Quercus cerris log, $47.98777^{\circ} \mathrm{N}, 19.00950^{\circ} \mathrm{E}$; leg. et det. V. Papp, 15.08.2014, BP 106939. - Hungary, Borsod-AbaújZemplén County, Bükk Mts: near Kisgyör, on Quercus cerris stump, $48.00242^{\circ} \mathrm{N}, 20.73547^{\circ} \mathrm{E}$; leg. B. Szűcs, det. V. Papp, 20.10.2014, BP 106940. - Hungary, Pest County, Buda Hills: near Budakeszi, on Quercus sp. log, $47.52194^{\circ} \mathrm{N}, 18.94250^{\circ}$ E; leg. I. Horváth, det. V. Papp, 02.02.2014, BP 106941.

Xylobolus P. Karst. s. str. is a small lignicolous corticioid genus in the russuloid clade (Russulales Kreisel ex P.M. Kirk et al.) characterised by simple-septate hyphae, smooth basidiospores, holocoenocylic nuclear behaviour, phenoloxidase negative reaction and causing white pocket-rot (BERNICCHIA and GORJóN 2010, Hiввет et al. 2014). The perennial, effused reflexed basidiocarp of $X$. subpileatus (Berk. et M. A. Curtis) Boidin is morphologically similar to Laxitextum bicolor (Pers.) Lentz or certain Stereum taxa (e.g. S. rugosum Pers.); however the brownish tomentose to felty abhymenial surface, the thickness, corky to hard texture, and the smooth to tuberculate, cracked hymenophore should distinguish it in the field. For detailed macro- and micromorphological features of this species see JAHN (1971), CHAMURIS (1988), BERNICCHIA and GorJón 2010; for the cultural description see NAKASONE (1990).

Xylobolus subpileatus (as Stereum subpileatum) was described from the United States (Ohio, South Carolina) and according to the literature, the distribution range of this species follows the oak zones throughout the Northern 
Hemisphere (e.g. Bernicchia and Gorjón 2010, Ghobad-Nejhad et al. 2009, JAHN 1971, ȚURA et al. 2008). In Central Europe it seems to be occurring on dead wood of Quercus cerris L. (JAHN 1971, TorTIć 1975).

Previous records and distribution of Xylobolus species (incl. X. subpileatus) in Hungary were discussed by PAPP (2011). In case of X. subpileatus, previously only a single proven record was documented in Hungary from the Juhdöglö-völgy Forest Reserve (Vértes Mts, Central Transdanubia). Herein, five new Hungarian records of this species are presented from the Buda Hills (Central Hungary), the Börzsöny Mts, and the Bükk Mts (Northern Hungary).

V. Papp

\section{Pteridophyta}

(29) Dryopteris affinis (Löwe) Fraser-Jenk. (Dryopteridaceae)

Hungary, Vas County, Köszeg Mts, Köszeg, in the valley of the stream Hármas-patak, in mixed forest, $47.380472^{\circ} \mathrm{N} 16.471472^{\circ} \mathrm{E}, 400 \mathrm{~m}$; leg. K. Baráth 14.08.2016, s.n. (hb Baráth).

D. affinis can be distinguished from Dryopteris filix-mas (L.) Schott. by its rectangular pinnulae, which are entire or partially dentate at the apex (but not serrate), as well as by the violet-black patch that can be observed at the base of the pinnae of Dryopteris affinis.

Dryopteris affinis occurs in Europe, northern Africa, Macaronesia, and southwestern Asia (WozIwoda 2009). In the continental part of Europe, it is considered to be a mountain species (FRASER-JENkins 2007). Although, this rare fern occurs more frequently in the western part of Hungary, it has not been reported from the Kőszeg Mts in the last 50 years (BodonCZI 1994, KIRÁly 1996).

In 2014 and 2015 two individuals of D. affinis were found in "Sötét-Völgy" [8664.4] (photodocumented, and in hb Baráth). In addition, in August 2016 a large population of this species was found in the valley of the stream Hármaspatak [8664.2]. Altogether 149 individuals were counted along the stream between $47.380472^{\circ} \mathrm{N}, 16.471472^{\circ} \mathrm{E}$ and $47.384916^{\circ} \mathrm{N} 16.461777^{\circ} \mathrm{E}$, but additional individuals were also observed in other locations of the Hungarian part of the mountains (e.g. $47.388694^{\circ} \mathrm{N}, 16.458694^{\circ} \mathrm{E}$ [8664.2] and $47.411444^{\circ} \mathrm{N}$ $16.462388^{\circ} \mathrm{E}$ [8564.4]). In the habitat of Dryopteris affinis the dominant tree species are Fagus sylvatica, Picea abies, Pinus sylvestris, and Carpinus betulus.

K. Baráth

(30) Dryopteris expansa (C. Presl) Fraser-Jenk. et Jermy (Dryopteridaceae)

Albania; District of Tropojë (Rrethi i Tropojës); between huts "stanet e Dërzhanës" and "Sjapicë" above village Çerem, in beech forest, $42.50468^{\circ} \mathrm{N}, 19.92790^{\circ} \mathrm{E}, 1709 \mathrm{~m}$; leg. Z. Barina and G. Somogyi, 12.08.2012, Nr. 21896 (BP). 
It is a circumpolar fern distributed in Europe mainly in the north and central parts; it is rare southwards and rather sporadically reported from the Balkans, its distribution is likely incompletely known. It occurs in North Greece (DimopouLOs et al. 2013); however, apparently missing in F. Y. R. of Macedonia (MICEVSKI 1985) and in Montenegro (Pulević 2005). The species is new for the flora of Albania.

Z. Barina

Angiospermatophyta

(31) Carpinus orientalis Mill. (Betulaceae)

Hungary, Somogy County, Örtilos, Szentmihályhegy, "Patacsin" ( $c a 1.2 \mathrm{~km} \mathrm{~N}$ of the railway station, E of the railway line), ca 150 m [9667.3]; leg. et det. E. Eperjessy, 1963, as "Ostrya carpinifolia".

Carpinus orientalis is widespread in the eastern Mediterranean, from S Italy to the mountains $S$ of the Caspian Sea (Sik kema and Caudullo 2016). In Croatia it is quite common in a narrow strip along the Adriatic coast; but presumably only introduced at few localities north of the Sava River; in Serbia its northernmost localities are known in the Fruška Gora Mts (Fekete and Blattny 1913, Ni kolić 2015). It has two "traditional" explicitly isolated occurrences in Hungary, both discovered in the 1950s. The population on the southern slopes of the Vértes Mts near Csákvár (Boros 1953) is considered to be the northernmost native occurrence of the species, whereas the stand found near the previous one in the Etyek Hills (KÁRPÁTI 1957) is probably of secondary origin.

Carpinus orientalis has never been reported from the hills $S$ of the Lake Balaton ("Dunántúli-dombság") in Hungary. In 2016 a non-expected occurrence came to be known under very strange circumstances: I found (among historical photographs) a well preserved dried fruiting specimen on the wall of the "Háromsárkány Inn" in Örtilos-Szentmihályhegy. The specimen (Fig. 1) was collected and labelled as "Ostrya carpinifolia" by Ernő Eperjessy, a recognised local historian, who (with the mediation of the owner of the inn, Zsuzsanna Béláné Zborovszky) kindly specified the place and habitat of the collection. The plant (a rather old tree of 20-25 cm diameter) was found at the time (1963) near houses on a forest fringe $\mathrm{N}$ of the railway station "Szentmihályhegy". This small settlement part has been reduced to a single entire house (several buildings were abandoned) by now, the presumed former locality is actually covered now by secondary woods dominated by black locust. A search for potential remnants of Carpinus orientalis tree(s) was unsuccessful in 2016. The misidentification of Carpinus for Ostrya can be easily understood knowing the also amazing story of the single Hungarian report of Ostrya carpinifolia from Örtilos Hills (KÁROLYI 


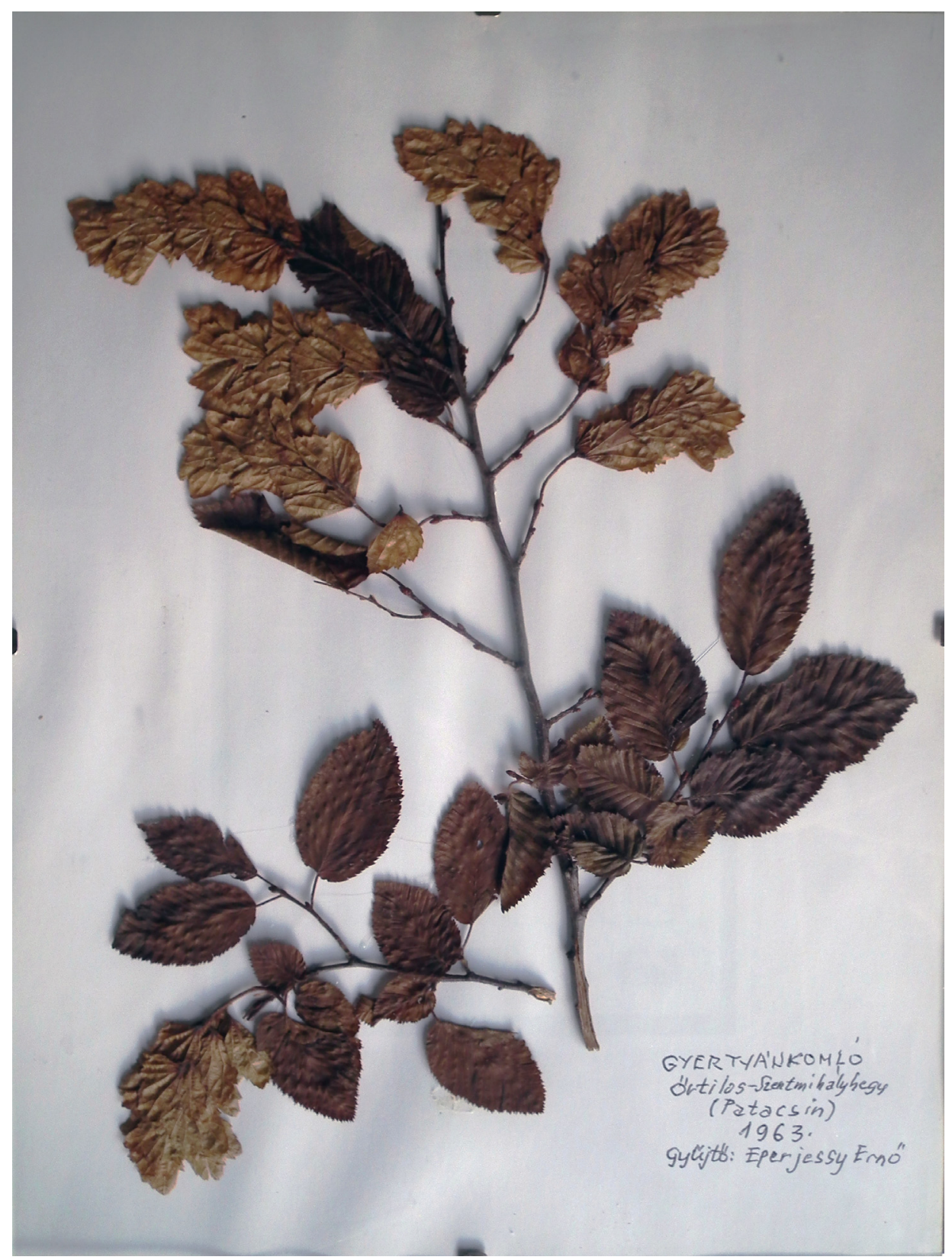

Fig. 1. The specimen of Carpinus orientalis Mill. collected in Örtilos, SW Hungary (kept in ÖrtilosSzentmihályhegy, "Háromsárkány Inn”; photographed by G. Király, 2016). 
and Pócs 1964). Thus, I have no doubts that the specimen was found and collected indeed in that area, and can be assessed as a surprising, but authentic "newold" record. However, its native status seems highly unlikely, because xerophilous forests are practically absent from the original vegetation of Örtilos Hills. The inhabitants of Szentmihályhegy had (especially until World War II) everyday commercial and family connections to Croatia, and C. orientalis was probably planted as ornamental tree of Croatian origin in this area.

G. Király

\section{(32) Deschampsia flexuosa (L.) Trin. (Poaceae)}

Hungary, Baranya County, Mecsek Mts: Kővágószőlös, Babás-szerkövek, along a forest path in an acidophytic sessile oak forest on a south-facing slope [9974/2]; $46.091538^{\circ} \mathrm{N}, 18.131972^{\circ} \mathrm{E}$, 446 m; leg.et det.: J. Csiky, 28.06.2016, s.n. (JPU).

One well developed tussock with several inflorescences was found along a forest path. Very likely, it is an adventive species here introduced by tourists or mountain bikers, new for the Mecsek Mts and its surroundings. The closest stands can be found approx. $70 \mathrm{~km}$ far from this locality, in the Papuk Mts (Croatia). In Hungary it occurs in the western part of the Transdanubia and in the North Hungarian Mts (BARTHA et al. 2015). Formerly it was also collected in the Bakony Mts, Balaton Uplands, and South Zala (nearby Csurgó) (HÉJJAS and BorHidi 1960) and reported from Soroksár (Soó 1973). Its occurrence has not been confirmed at the above localities and the latter two are doubtfully native and/or highly unlikely occurrences, since the landscape of these areas lacks conditions (e.g. high relief, hard bedrock) which are essential for Luzulo-Fagion and Quercetalia roboris vegetation preferred by D. flexuosa in Hungary (Soó 1973, KevEY 2008).

Associated species in the approx. $16 \mathrm{~m}^{2}$ sized forest patch between the path and a sandstone cliff are Quercus petraea, Fraxinus ornus, Polygonatum odoratum, Luzula luzuloides, and Rumex acetosella. These taxa are typical and widespread elements of the acidophilous oak forests in the Mecsek Mts (KEVEY and BORHIDI 2005).

Since potential habitats (acidophilous oak and beech forests) of $D$. flexuosa are widespread in the Mecsek Mts, further research and monitoring of this new and supposedly introduced species are strongly recommended.

J. Csiky

\section{(33) Dittrichia graveolens(L.) Greuter (Asteraceae)}

Hungary, Győr-Moson-Sopron County, Lesser Plain (Kisalföld), Töltéstava: along the motorway M1 (side Vienna-Budapest), Székesfehérvár exit, 20 metres from the junction to main road 81 , one specimen growing near the verge of the road, $47.647838^{\circ} \mathrm{N}, 17.712761^{\circ} \mathrm{E}, 122 \mathrm{~m}$ [8372.3], 14.09.2013; leg. et det.: D. Schmidt (photodocumented). 
It is reported for the first time from Hungary. This thermophilous species is originally native to the Mediterranean region, where it prefers disturbed and cultivated lands, abandoned fields, roadsides, ruderal places, and other anthropogenic habitats (BRULLO and DE MARCO 2000). After the successful invasion along German and Austrian motorways (RADкоwiтsch 2003, HoHLA 2001, STÖHR et al. 2012) it reached the neighbouring countries towards East Central Europe. Consequently, it is reported from Slovenia (FraJMAN and KALIGARIČ 2009), the Czech Republic (RAABE 2009), Slovakia (KirÁly et al. 2014), and Poland (Kocián 2015). The closest stand to Hungary was known from the flora quadrant 8067.1 along the A4 motorway in Austria (STöнR et al. 2012), about 22 $\mathrm{km}$ from the Hungarian border and $75 \mathrm{~km}$ from the new locality near Töltéstava. The Hungarian motorway M1 is part of the E-Class road E60 and E75 with direct connection to motorway A4 in Austria. Knowing the species' recent invasion history, first emergence in Hungary is not surprising. However, the species disappeared from the first locality by 2014 , and no other founds have been reported up to now. Based on the developing unified motorway-network in Central Europe, despite of the decrease of further spreading in the recent years, newly naturalised stands in Hungary are still expected in the near future.

D. Schmidt

\section{(34) Eleocharis uniglumis (Link) Schult. (Cyperaceae)}

Hungary, Borsod-Abaúj-Zemplén County, Zemplén Mts: Erdőbénye, Nagy-rétek, in depressions of mesophytic meadows; $48.24060^{\circ} \mathrm{N}, 21.38180^{\circ} \mathrm{E}, 113 \mathrm{~m}$ [7794.3]; leg. A. Takács and T. Nagy, 24.06.2016 (DE-Soo-43228).

Eleocharis uniglumis (Link) Schult. is a member of E. palustris group. The species is widespread in Europe (WALTERS 1980), but the distribution of this taxon in fine scale is uneven, or at least incompletely known (cf. WALTERS 1949, KAPLAN et al. 2015, Wör et al. 2016). In Hungary, E. uniglumis is relatively frequent in the Great Plain, sporadic in the northern part of Transdanubia, and especially rare in South-Transdanubia and in the North Hungarian Mts (LÁJER 2009, BARTHA et al. 2015). During a field trip, the authors found some fruiting specimens of E. uniglumis in an Iris pseudacorus dominated marsh patch at the valley of Bényei-patak. Occurrence of the species has not been indicated from the Zemplén Mts by archive floristic studies (HAZsLinszKy 1866, Kiss 1939, Hargitai and Soó 1940), neither by the numerous recent studies. However, it is probably also present in other wide brook-valleys which has direct connection with the surrounding flood basins.

In the surroundings of the above presented locality, presence of E. uniglumis has been reported from the upper part of Bodrogköz (MARGITTAI 1929), the Bódva Valley (VIrók and FARKas 2007), and from the Cserehát Hills (Virók et al. 2010). 
(35) Himantoglossum adriaticum $\mathrm{H}$. Baumann (Orchidaceae)

Hungary, Pest County, "Ecskendi-dombság”, Aszód [probably 8382.2]; leg. et det. J. Rigler 15.06.1928., as "Loroglossum hircinum (L.) Rich." (BRA).

The taxonomical division of genus Himantoglossum in Central Europe was very confused for a long time (Bódis and ALMÁdi 1998, MOLNÁR et al. 2012). $H$. adriaticum was described by BAUMANN (1978) together with outlining its distribution which includes parts of Italy, Austria, Slovenia, Croatia, Czech Republic, Slovakia, and Hungary, and only slightly overlaps with other taxa of the genus. Known Hungarian localities of $H$. adriaticum are restricted mostly to Western Transdanubia, so far known only from Mt Nagy-Eged at Eger eastwards (SULYOK et al. 1998). The species was collected in this locality two times (in 1816 and 1870), without later confirmation, despite the mount being one of the most frequently visited place in the Bükk Mts, thus it is regarded to be extinct from there (SULYOK et al. 1998).

An additional record of $H$. adriaticum in the North Hungarian Mts was recognised during a herbarium data collection in Bratislava (BRA, Slovakia). The specimen was collected by József Rigler under the name "Loroglossum hircinum". Description of the locality represents unfortunately just a single settlement name, "Aszód" without specifying the locality. We have no information on Himantoglossum occurrences in this area (cf. SULYOK et al. 1998, BARTHA et al. 2015) or on the activities of Rigler here. According to the letterhead of the label, the sheet originated from the former "Seed Testing Station of Budapest", which was the workplace of Rigler from 1927. However, previously he spent a long time in Keszthely, where the largest Hungarian populations of $H$. adriaticum are known.

The single, flowering shoot is clearly identified as $H$. adriaticum based on the size of the flower, length of the spur, and width of the labellum's lobe.

If the above mentioned locality is correct, this record is new to the Cserhát Mts and is the second occurrence in the North Hungarian Mountains. Without recent confirmation, the species should be regarded to be extinct here; nevertheless, recent surveys of potential habitats in the southern foothills of the Cserhát Mts are recommended.

T. Nagy and A. Takács

(36) Moneses uniflora (L.) A. Gray (Ericaceae)

Hungary, Baranya County, Mecsek Mts: Abaliget, railway station, in a 37 years old spruce plantation (subcompartment 3B), 46.150508 N, 18.077969 E, 203 m [9874/1]; leg. J. Csiky, É. Csikyné R., B. Tamási and P. Tamási, 27.06.2016, det.: J. Csiky, s.n. (JPU).

Although the taxa of the tribe Pyroleae (within the Ericaceae family) spread easily, in lack of suitable natural habitats they are rather rare in Hungary. It is par- 
ticularly true for the Southern Transdanubia, since only three species have been mentioned before in the region (FAR KAS 1999): Pyrola minor, P. rotundifolia, and Orthilia secunda.

Moneses uniflora is one of the rarest species among Ericaceae taxa in Hungary and new for the whole Southern Transdanubia. According to the distribution map of BARTHA et al. (2015) there are only a few actual stands in the country, i.e. in the Western Transdanubia (Örség, Vendvidék), in the Transdanubian Mts (Vértes), and in the North Hungarian Mts (Bükk, Aggteleki-karszt, Zemplén Mts). Formerly it was also mentioned from the Börzsöny, Bakony, Keszthely, Sopron, and Köszeg Mts, Göcsej, nearby Szombathely and Nyírbakta (Soó 1968), but it has recently not been confirmed in these places. In the case of the Börzsöny Mts this species was not listed in the critical revision of the vascular flora (NAGY 2007).

Moneses uniflora usually occurs in coniferous forests, frequently in spruce plantations (VojtKó 2001, Király 2002, KirÁly 2004, Virók et al. 2016). Since lifetime of such productive forests is rather short (40-80 years), stable populations of this pioneer species are very rare in Hungary.

Associated species according to two phytocoenological relevés (taken by the authors in 27th June 2016, plot size $25 \mathrm{~m}^{2}$ ) are the followings:

Relevé 1: $46.150508^{\circ} \mathrm{N}, 18.077969^{\circ} \mathrm{E}$, Elevation: $203 \mathrm{~m}$, Total cover in E3: 70\%, Height E3: $15 \mathrm{~m}$, Total cover in E2: 2\%, Height E2: 1,5 m, Total cover in E1: 2\%, Height E1: $50 \mathrm{~cm}$. Tree layer (E3): Picea abies 70\%; Shrub layer (E2): Fagus sylvatica 2\%, Populus tremula $r$, Quercus petraea $r$, Rubus sp. +; Herb layer (E1): Acer pseudoplatanus $r$, Angelica sylvestris $r$, Campanula patula $r$, Carex sylvatica + , Dryopteris carthusiana $r$, Equisetum arvense $r$, Hedera helix $r$, Hieracium sabaudum 3, Luzula forsteri $r$, Melampyrum pratense + , Moneses uniflora + , Picea abies + , Populus tremula + , Torilis japonica $r$, Veronica officinalis + , Viola reichenbachiana +. Relevé 2: $46.150713^{\circ} \mathrm{N}, 18.077986^{\circ} \mathrm{E}$, Elevation: $200 \mathrm{~m}$, Total cover in E3: 60\%, Height E3: $15 \mathrm{~m}$, Total cover in E2: 2\%, Height E2: $2 \mathrm{~m}$, Total cover in E1: 5\%, Height E1: $50 \mathrm{~cm}$. Tree layer (E3): Picea abies 60; Shrub layer (E2): Fagus sylvatica r, Picea abies 2; Herb layer (E1): Ambrosia artemisiifolia r, Aremonia agrimonioides 2, Campanula patula + , Carpinus betulus $r$, Chaerophyllum temulum $r$, Cornus sanguinea $r$, Crataegus monogyna $r$, Daucus carota $r$, Euonymus europaeus $r$, Fagus sylvatica $r$, Festuca gigantea $r$, Galeopsis pubescens $r$, Hedera helix + , Hieracium sabaudum + , Lycopodium clavatum + , Moneses uniflora + , Picea abies + , Rosa canina $r$, Rubus sp. + , Sanicula europaea $r$, Veronica officinalis + , Vicia tetrasperma $r$, Viola reichenbachiana + .

The three small $\left(0.5 \mathrm{~m}^{2}\right)$ patches of $M$. uniflora were checked in September and October, but flowering stem was not found.

J. Csiky, É. R. Csikyné and B. Tamási 


\section{(37) Salvia aethiopis L.}

Albania, county of Korçë (Qarku i Korçës); between village Kapshticë and town Bilisht along main road SH3, by the roadside, $40.611873^{\circ} \mathrm{N}, 20.997982^{\circ} \mathrm{E}$; leg.: Z. Barina, K. Baráth and G. Puskás, 13.06.2016. - The same locality; leg.: Z. Barina, H. Mező and L. Papp, 16.08.2016, Nr. 30508 a

Flowering plants were observed and recorded along the roadside on the way from Budapest (Hungary) to Korça (Albania) in the morning of 13.06.2016. This time, the importance of the occurrence was not recognised, and being the first record of the species in Albania, the locality was visited again in the summer. At that time, withered plants were observed and collected with fresh basal rosettes, and the previous identification was confirmed.

S. aethiopis is not rare in the Eastern parts of the Balkan Peninsula (cf. Assyov and Petrova 2006); however, rather sporadic westwards (Dimopoulos et al. 2013), missing in Montenegro (PULEVIĆ 2005), and questionably occurs in Croatia (Flora Croatica Database). The species is new for the flora of Albania.

Z. Barina and K. Baráth

Acknowledgements - Work of Zoltán Barina was supported by the Hungarian Scientific Research grant (OTKA 104443). Work of Timea Nagy was supported by the New National Excellence Program of the Ministry of Human Capacities. Work of Attila Takács was supported by NTPEFÖ-P-15 project. T. Nagy and A. Takács are very thankful to Pavol Mered'a for his very kind assistance in the herbarium work. János Csiky would like to thank the colleagues of Mecsekerdö Zrt. for their helpful assistance in the survey of spruce plantations in the Mecsek Mts.

Összefoglaló: Jelen közleményünk a tavaly megkezdett, regionális jelentőségű előfordulásokat és nevezéktani megjegyzéseket tartalmazó sorozat harmadik része. Ebben a részben egy gombafaj, két páfrányfaj és hét virágos növény faj adatait ismertetjük. Közülük a Dittrichia graveolens új Magyarország flórájára, a hegyi pajzsika (Drypoteris expansa) és a magyar zsálya (Salvia aethiopis) pedig Albánia flórájára. A keleti gyertyán (Carpinus orientalis) új a Dunántúli-dombságra, az erdei sédbúza (Deschampsia flexuosa) és az egyvirágú körtike (Moneses uniflora) a Mecsekre és a Dél-Dunántúlra, az adriai sallangvirág (Himantoglossum adriaticum) a Cserhátra, az egypelyvás csetkáka (Eleocharis uniglumis) a Zempléni-hegységre, a Xylobolus subpileatus pedig a Börzsönyre, Bükkre és Budai-hegységre is, a pelyvás pajzsika (Dryopteris affinis) előfordulása a Köszegi-hegységben pedig megerősítést nyert. Ez utóbbi faj és a keleti gyertyán ez ideig csak egy-egy lelőhelyről volt ismert hazánkban, a többi faj pedig regionálisan ritka az ország területén. A keleti gyertyán az itt közölt lokalitáson feltehetỏen ültetett volt, míg a Dittrichia graveolens behurcolt, az erdei sédbúza pedig szintén valószínüleg behurcolt lehet.

\section{REFERENCES}

Assyov, B. and Petrova, A. (2006): Conspectus of the Bulgarian vascular flora. - Bulgaria Biodiversity Foundation, Sofia, $454 \mathrm{pp}$. 
Barina,Z., Benede K, L., Boros, L., Dima, B., Folcz, Á., KirÁly, G., Koszka, A., Malatinszky, Á., PApp, D., Pifkó, D. and PAPp, V. (2015): Taxonomical and chorological notes 1 (1-19). Studia bot. hung. 46(2): 205-222. http://dx.doi.org/10.17110/studbot.2015.46.2.205

Bartha, D., Király, G., Schmidt, D., Tiborcz, V., Barina, Z., Csiky, J., Jakab, G., Lesku, B., Schmotzer, A., Vidéki, R., Vojtкó, A. and Zólyomi, Sz. (2015): Magyarország edényes növényfajainak elterjedési atlasza. [Distribution of vascular plants of Hungary]. - Nyugatmagyarországi Egyetem Kiadó, Sopron, 276 pp.

BAUMANN, H. (1978): Himantoglossum adriaticum Baumann - eine bislang übersehene Riemenzunge aus dem zentralen nördlichen Mittelmeergebiet. - Orchidee 29(4): 165-172.

BernicChia, A. and Gorjón, S. P. (2010): Corticiaceae s. l. - Fungi Europaei 12., Edizioni Candusso, Alassio, 1008 pp.

Bódis, J. and AlmÁdi, L. (1998): Himantoglossum adriaticum a Keszthelyi-hegységben. - Bot. Közlem. 85: 73-79.

Bodonczi, L. (1994): A Köszegi-hegység harasztflórája. - In: BARTHA, D. (ed.): A Kőszegi-hegység vegetációja. Private edition, Kőszeg-Sopron, pp. 42-53.

Boros, Á. (1953): Florisztikai közlemények IV. [Floristic records IV]. - Bot. Közlem. 45: 276-279.

Brullo, B. and De MARCo, G. (2000): Taxonomical revision of the genus Dittrichia (Asteraceae). - Portug. Acta Biol. 19: 341-354.

Chamuris, G. P. (1988): The non-stipitate steroid fungi in the northeastern United States and adjacent Canada. - Mycol. Memoirs 14: 1-247.

Dimopoulos, P., Raus, Th., Bergmeier, E., Constantinidis, Th., Iatrou, G., Kokkini, S., Strid, A. and Tzanoudakis, D. (2013): Vascular plants of Greece. An annotated checklist. - Englera 31: 1-372.

FARKAs, S. (ed.) (1999): Magyarország védett növényei. [Legally protected vascular plants of Hungary]. - Mezőgazda Kiadó, Budapest, 416 pp.

Fenete, L. and Blatt ny, T. (1913): Az erdészeti jelentöségü fák és cserjék elterjedése a Magyar Állam területén I-II. [Distribution of forest tree and shrub species in the Hungarian State I-II]. Joerges Ágost özvegye és fia könyvnyomdája, Selmecbánya, $793+150$ pp.

FRAJMAN, B. and KALIGARIČ, M. (2009): Dittrichia graveolens, nova tujerodna vrsta slovenske flore. - Hladnikia 24: 35-43.

Fraser-Jenkins, C. R. (2007): The species and subspecies in the Dryopteris affinis group. - Fern Gazette 18(1): 1-26.

Ghobad-Nejhad, M., Hallenberg, N., Parmasto, E. and Kotiranta, H. (2009): A first annotated checklist of corticioid and polypore basidiomycetes of the Caucasus region. - Mycol. Balcan. 6: 123-168.

Hargitai, Z. and Soó, R. (1940): A Sátorhegység flórájáról. - Bot. Közlem. 37: 169-187.

Hazslinszky, F. (1866): A Tokaj-Hegyalja viránya. - Math. term.tud. Közlem. 4: 105-143.

HéJjAs, I. and Borhidi, A. (1960): Csurgó és környéke flórája. - Bot. Közlem. 48(3-4): 245-256.

Hibbett, D. D., Bauer, R., Binder, M., Giachini, A. J., Hosaka, K., Justo, A., Larsson, E., Larsson, K. H., Lawrey, J. D., Miettinen, O., Nagy, L., Nilsson, R. H., Weiss, M. and Thorn, R. G. (2014): Agaricomycetes. - In: Mclaughlin, D. J. and Spatafora, J. W. (eds): The Mycota. Vol. VII. 2nd ed., Part A. Systematics and Evolution. Springer Verlag, pp. 373-429.

HoнlA, M. (2001): Dittrichia graveolens (L.) Greuter, Juncus ensifolius Wikstr. und Ranunculus penicillatus (Dumort.) Bab. neu für Österreich und weitere Beitrage zur Kenntnis der Flora des Innviertels und des angrenzenden Bayerns. - Beitr. Naturk. Oberösterreichs 10: 275-353.

Jahn, H. (1971): Stereoide Pilze in Europa (Stereaceae Pil. emend. Parm. u. a., Hymenochaete), mit besonderer Berücksichtigung ihres Vorkommens in der Bundesrepublik Deutschland. Westf. Pilzbr. 8: 69-176. 
Kaplan, Z., Danihelka, J., ŠtěpÁn ková, J., Bureš, P., Zázvorka, J., Hroudová, Z., DucháČex, M., Grulich, V., Řepka, R., Dančák, M., Pranc, J., Šumberová, K., Wild, J. and TrÁvníčeK, B. (2015): Distributions of vascular plants in the Czech Republic. Part 1. Preslia 87: 417-500.

KÁROLYI, Á. and Pócs, T. (1964): Újabb adatok Délnyugat-Dunántúl flórájához III. [New records on the flora of SW Transdanubia III]. - Vas Megyei Múzeumok Értesitoóje 2: 43-54.

KÁRPÁTI, Z. (1957): Ribes petraeum Wulf., Magyarország új növénye és néhány florisztikai adat. [Ribes petraeum Wulf., new to Hungary and some further floristic records]. - Bot. Közlem. 47: 113-114.

KeVEy, B. (2008): Magyarország erdőtársulásai. [Forest associations of Hungary]. - Tilia 14: 3-489.

Kevey, B. and Borhidi, A. (2005): The acidophilous forests of the Mecsek and their relationship with the Balkan-Pannonian acidophilous forests. - Acta Bot. Hung. 47(3-4): 273-368.

KIRÁLY, G. (1996): A Kőszegi-hegység edényes flórája. - Tilia 3: 1-415.

KirÁLY, G. (ed.) (2002): Az Örség és a Vendvidék védett és veszélyeztetett edényes növényei. [Legally protected and threatened vascular species of Örség and Vendvidék]. - Kanitzia 10: 61-108.

KirÁLY, G. (ed.) (2004): A Soproni-hegység edényes flórája. (Vascular flora of the Sopron Hills). Flora Pannonica 2(1): 1-507.

KirÁLY, G. (ed.) (2009): Új magyar füvészkönyv. Magyarország hajtásos növényei. Határozókulcsok. (New Hungarian Herbal. The vascular plants of Hungary. Identification key). - Aggteleki Nemzeti Park Igazgatóság, Jósvafö, 616 pp.

Király, G., Eliáš, P. jun. and DítĚ, D. (2014): Two thermophilic alien species new to the flora of Slovakia. - Thaiszia, J. Bot. 24: 125-134.

KIss, Á. (1939): Adatok a Hegyalja flórájához. - Bot. Közlem. 36: 181-273.

Kocián, P. (2015): Dittrichia graveolens (L.) Greuter - a new alien species in Poland. - Acta Mus. Siles. Sci. Natur. 64: 193-197. https://doi.org/10.1515/cszma-2015-0027

LÁJer, K. (2009): Eleocharis R. Br. - Csetkáka. - In: KirálY, G. (ed.): Új magyar füvészkönyv. Magyarország hajtásos növényei. Határozókulcsok. Aggteleki Nemzeti Park Igazgatóság, Jósvafö, pp. 549-551.

Margittai, A. (1929): Szomotor homokjának flórája. - Bot. Közlem. 26: 26-32.

Micevs KI, K. (ed.) (1985): Flora na Republika Makedonija. Vol. 1(1). - Makedonska Akademija na naukite i umetnostite, Skopje, $152 \mathrm{pp}$.

Molnár, A., Kreutz, K. C., Óvári, M., Sennikov, A. N., Bateman, R. M., Takács, A., SomLYAY, L. and SRAM Kó, G. (2012): Himantoglossum jankae (Orchidaceae: Orchideae), a new name for a long-misnamed lizard orchid. - Phytotaxa 73(1): 8-12.

NAGY, J. (2007): A Börzsöny hegység edényes flórája. (Vascular flora of the Börzsöny Mountains). Duna-Ipoly Nemzeti Park Igazgatóság, Budapest, 378 pp.

NAKASONE, K. K. (1990): Cultural studies and identification of wood-inhabiting Corticiaceae and selected Hymenomycetes from North America. - Mycol. Memoirs 15: 1-412.

Ni Kolić, T. (ed.) (2015): Flora Croatica Database. - Faculty of Science, University of Zagreb, published on the internet, http://hirc.botanic.hr/fcd (accessed 24.09.2016).

PAPP, V. (2011): Adatok a Xylobolus nemzetség magyarországi előfordulásáról. (Data on the Hungarian occurrences of the genus Xylobolus). - Mikol. Közlem., Clusiana 50(2): 173-182.

Papp, V., Dima, B., Király, G., Koscsó, J., Malatinszky, Á., Nagy, T. and Takács, A. (2016): Taxonomical and chorological notes 2 (20-27). - Studia bot. hung. 47(1): 179-191. http://dx.doi.org/10.17110/StudBot.2016.47.1.179 
Pulević, V. (2005): Material for vascular flora of Montenegro. A supplement to "Conspectus Florae Montenegrinae" (J. Rohlena). - Cicero, Cetinje, 218 pp.

RAABE, U. (2009): Dittrichia graveolens (L.) Greuter. In: HAdieC, J. and Lustyk, P. (eds): Additamenta ad floram Reipublicae Bohemicae VIII. - Zprávy Čes. Bot. Společ. 44: 235-238.

RAD Kowitsch, A. (2003): Neophytic plants in Bavaria (Senecio inaequidens and Dittrichia graveolens). - In: ZAJĄC, A., ZajĄC, M. and ZemaneK, B. (eds): Phytogeographical problems of synanthropic plants. Institute of Botany, Jagiellonian University, Cracow, pp. 47-61.

Si KKema, R. and CAUdullo, G. (2016): Carpinus orientalis in Europe: distribution, habitat, usage and threats. - In: SAn-Miguel-Ayanz, J., de Rigo, D., Caudullo, G., Houston DurRANT, T. and MAURI, A. (eds): European atlas of forest tree species. Publication Office of the European Union, Luxembourg, $197 \mathrm{pp}$.

Soó, R. (1968): A magyar flóra és vegetáció rendszertani-növényföldrajzi kézikönyve III. (Synopsis systematico-geobotanica florae vegetanionisque Hungariae III). - Akadémiai Kiadó, Budapest, $506 \mathrm{pp}$.

Soó, R. (1973): A magyar flóra és vegetáció rendszertani-növényföldrajzi kézikönyve V. (Synopsis systematico-geobotanica florae vegetanionisque Hungariae V). - Akadémiai Kiadó, Budapest, $723 \mathrm{pp}$.

Stöhr, O., Pilsl, P., Staudinger, M., Kleesadl, G., Essl, F., Englisch, T., Lugmair, A. and Wittmann H. (2012): Beiträge zur Flora von Österreich, IV. - Stapfia 97: 53-136.

SUlYOK, J., VidÉKI, R. and MOLNÁR, A. (1998): Adatok a magyarországi Himantoglossum-fajok ismeretéhez. - Kitaibelia3(2): 223-229.

The Plant List (2013). Version 1.1. Published on the Internet. - http://www.theplantlist.org/ (accessed 11.11.2016).

Tortić, M. (1975): Two interesting Sterea new for Jugoslavia: Xylobolus subpileatus (Berk. et Curt.) Boid. and Stereum reflexulum Reid. - Acta Bot. Croat. 34: 139-142.

Țura, D., Zmitrovich, I. V., Wasser, S. P. and Nevo, E. (2008): The genus Stereum in Israel. Mycotaxon 106: 109-126.

Virók, V. and FARKAS, R. (2007): Florisztikai adatok Borsod-Abaúj-Zemplén megye északi részéröl II. - Kitaibelia 12: 73-79.

ViróK, V., FARKas, R., Gulyás G. and SRAmKó, G. (2010): Florisztikai adatok Borsod-AbaújZemplén megye északi részéről III. - Kitaibelia 15: 73-84.

Virók, V., FARKas, R., FARKas, T., ŠUVAda, R. and Vojt Kó, A. (2016): A Gömör-Tornai-karszt flórája, Enumeráció. Flóra Gemersko-turnianskeho krasu, Enumerácia. (Vascular flora of the Gömör-Torna Carst, Enumeration). - Aggteleki Nemzeti Park Igazgatóság, Jósvafö, 200 + $910 \mathrm{pp}$.

Vojt Kó, A. (ed.) (2001): A Bükk hegység flórája. [Vascular flora of the Bükk Mts]. - Sorbus 2001, Eger, $340 \mathrm{pp}$.

WalteRs, S. M. (1949): Eleocharis R. Br. - J. Ecol. 37: 192-206. https://doi.org/10.2307/2256753

Walters, S. M. (1980): Eleocharis R. Br. - In: Tutin, T. G., Heywood, V. H., Burges, N. A., Moore, D. M., Valentine, D. H., Walters, S. M. and Webb, D. A. (eds): Flora Europaea 5. Cambridge University Press, pp. 281-284.

Wörz, A., Engelhardt, M., Hölzer, A. and Thiv, M. (2016): Aktuelle Verbreitungskarten der Farn- und Blütenpflanzen Baden-Württembergs. - published on the internet, http://www. flora.naturkundemuseum-bw.de (accessed 10.11.2016)

Wozrwoda, B. (2009): Morphological diversity of ferns in the Dryopteris affinis group in Central Poland. - In: SzCZz̨śniak, E. and Gola, E. (eds): Genus Dryopteris Adans. in Poland. Polish Botanical Society and Institute of Plant Biology, University of Wrocław, Wrocław, pp. 45-59. 